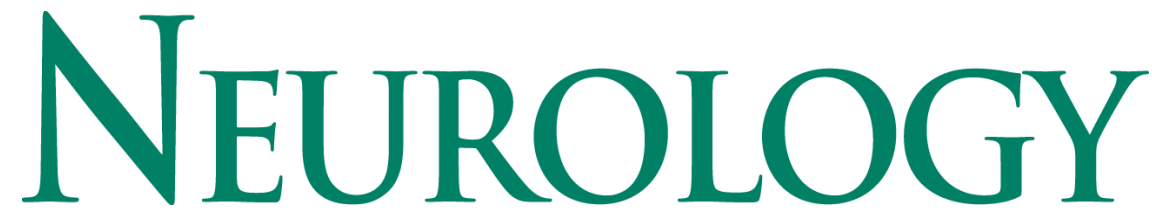

\title{
Cervical artery dissection: An atypical presentation with Ehlers-Danlos-like collagen pathology?
}

D. Ulbricht, N. J. Diederich, T. Hermanns-Lê, R. J. Metz, F. Macian and G. E. Piérard Neurology 2004;63;1708-1710

This information is current as of March 3, 2009

The online version of this article, along with updated information and services, is located on the World Wide Web at:

http://www.neurology.org/cgi/content/full/63/9/1708

Neurology ${ }^{\circledR}$ is the official journal of the American Academy of Neurology. Published continuously since 1951, it is now a weekly with 48 issues per year. Copyright $(2004$ by AAN Enterprises, Inc. All rights reserved. Print ISSN: 0028-3878. Online ISSN: 1526-632X.

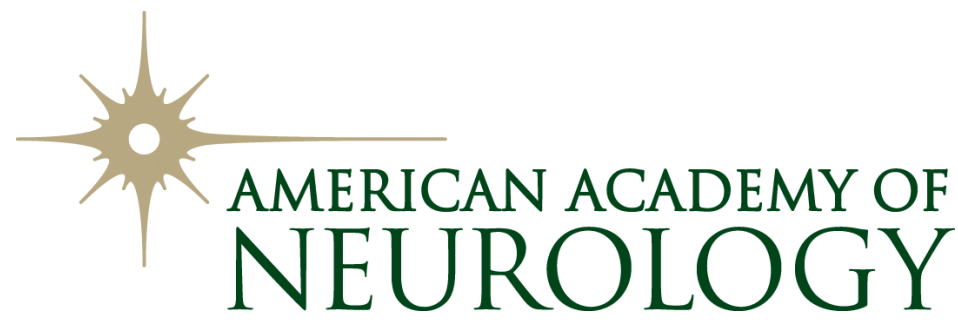




\title{
Cervical artery dissection
}

\section{An atypical presentation with Ehlers-Danlos-like collagen pathology?}

\author{
D. Ulbricht, MD; N.J. Diederich, MD; T. Hermanns-Lê, MD; R.J. Metz, MD; F. Macian, MD; \\ and G.E. Piérard, MD
}

\begin{abstract}
The authors took skin biopsies of the macroscopically normal skin of seven consecutive patients with spontaneous cervical artery dissection (SCAD). Histologically, alterations of the collagen and elastic fiber networks were found in six patients. In five, the histologic, immunohistochemical, and ultrastructural changes were similar to those usually found in Ehlers-Danlos syndrome (EDS). This suggests that SCAD is frequently associated with the dermal alterations seen in EDS.
\end{abstract}

NEUROLOGY 2004;63:1708-1710

Spontaneous cervical artery dissection (SCAD) is the most frequent cause of stroke in young adults. ${ }^{1}$ Risk factors for SCAD include minor trauma, migraine, hyperhomocysteinemia, and rare disorders such as fibromuscular dysplasia, Marfan syndrome, or Ehlers-Danlos syndrome (EDS), especially the type IV (vascular variant). ${ }^{2}$ Vessel wall and uterine ruptures predominantly express the latter type, and affected individuals are prone to SCAD. ${ }^{3}$ Pathologically altered skin collagen recently has been demonstrated in patients with SCAD lacking clinical evidence for any specific connective tissue disorder (CTD). ${ }^{4} \mathrm{We}$ designed the present prospective study to further explore the skin collagen structure in SCAD.

Patients and methods. In a primary care hospital, seven consecutive patients were treated for SCAD from October 1999 to September 2002. The diagnosis was based on clinical (local symptoms and stroke) and paraclinical findings (Duplex ultrasound, MRI, and angiography). The patients were four women and three men aged from 29 to 48 years (mean, 39 years). There was no history of major trauma or vascular risk factors, including the intake of sympathomimetic drugs. We applied the Villefranche criteria for EDS for clinical diagnosis of CTD. ${ }^{5}$ Skin biopsies (SBs) taken from the mid-dermis were assessed by light microscopy (staining techniques: hematoxylin-eosin, orcein-Giemsa, WarthinStarry, Sirius red, Masson trichrome, periodic acid-Schiff-colloidal iron), immunohistochemistry for factor XIIIa (dermal dendrocyte), and electron microscopy.

Five patients gave written consent, and two globally aphasic patients with agraphia and alexia gave witnessed oral consent.

Results. Five of the patients did not fulfill clinical criteria for the known EDS subtypes, Marfan syndrome, pseudoxanthoma elasticum, and any other CTD. One patient had clinical features suggestive of EDS I, and the clinical course of another patient with two radial artery dissections caused by repeated puncture during her stay in the intensive care unit fitted to EDS IV. There was no inflam- mation, no hyperhomocysteinemia, and no evidence of fibromuscular dysplasia on angiography (table). Peculiar microscopic changes were disclosed in the dermis of six patients. Four patients displayed a disorganized pattern of elastic fibers, two of them having a fragmented ultrastructural aspect of these fibers. Collagen bundles were thin and oriented in a haphazard pattern $(n=4)$. Electron microscopy showed twisted collagen fibrils of various diameters, loose bundles with irregular interfibrillar spaces, and excessive amorphous matrix $(n=5)$. In four patients, the endoplasmic reticulum of fibroblasts was dilated and enriched in granular material (see table and figure). These aspects were consistent with EDS IV in two patients, unclassifiable EDS in three, borderline atypical elastopathy in one, and normal connective tissue in one. Histologically, the skin microvasculature was normal. The density in dermal dendrocytes ranged from low $\left(<50 / \mathrm{mm}^{2}\right)$ to normal $(75$ to $95 / \mathrm{mm}^{2}$ ). The histologic phenotype of the patients with clinical findings suggestive of EDS did not differ from those without stigmata.

Discussion. In six of seven patients with SCAD, the skin contained an abnormal connective tissue matrix. This suggests a causal link between SCAD and an abnormal structure of the connective tissue. Brandt et al. ${ }^{4}$ described a comparable connection in their selected, retrospective, and laboratory-based series. Pathologic collagen structures appeared in 31 of 55 of their SCAD cases (56.3\%). ${ }^{4}$ Minor risk factors, normally insufficient to induce arterial wall rupture alone, could thus facilitate SCAD in a fragile, but previously asymptomatic, vessel wall.

It has not escaped our attention that the present series carries a high frequency of pathologic changes commonly seen in clinically obvious EDS even in patients devoid of EDS stigmata. This implies that there may be a yet-unrecognized EDS type prone to

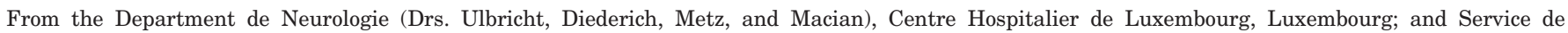
Dermatopathologie (Drs. Hermanns-Lê and Piérard), University Hospital of Liège, Belgium.

Received February 5, 2003. Accepted in final form June 21, 2004.

Address correspondence and reprint requests to Dr. Dirk Ulbricht, 23-25 rue de l'Alzette, Esch-sur-Alzette, L-4011, Luxembourg; e-mail: ulbricht@macnews.de 
Table Patients treated for SCAD from October 1999 to September 2002

\begin{tabular}{|c|c|c|c|c|c|c|c|}
\hline $\begin{array}{l}\text { No./ } \\
\text { age, y/ } \\
\text { sex }\end{array}$ & $\begin{array}{l}\text { Site of dissection/ } \\
\text { lesion }\end{array}$ & $\begin{array}{l}\text { Trauma, risk } \\
\text { factors/preceding } \\
\text { symptoms }\end{array}$ & Symptoms & Signs of CTD & $\begin{array}{l}\text { Light microscopy/ } \\
\text { immunohistochemistry }\end{array}$ & Electron microscopy & Conclusion \\
\hline $1 / 44 / \mathrm{F}$ & $\begin{array}{l}\text { Occlusion of the } \\
\text { right ICA. } \\
\text { Incomplete } \\
\text { right MCA } \\
\text { stroke. }\end{array}$ & $\begin{array}{l}\text { No. Occurred } \\
\text { while jogging. } \\
\text { Raeder } \\
\text { syndrome on the } \\
\text { left } 4 \text { years } \\
\text { before. }\end{array}$ & $\begin{array}{l}\text { Left hemiparesis, } \\
\text { supramodal } \\
\text { hemineglect, } \\
\text { disturbed body } \\
\text { scheme. }\end{array}$ & $\begin{array}{l}\text { Dissections of } \\
\text { both radial } \\
\text { arteries } \\
\text { during her } \\
\text { hospital stay } \\
\text { following } \\
\text { repeated } \\
\text { punctures. } \\
\text { Dilated aorta. }\end{array}$ & $\begin{array}{l}\text { Disorganized collagen } \\
\text { bundles and elastic } \\
\text { fibers. Normal } \\
\text { density in } \\
\text { dendrocytes. }\end{array}$ & $\begin{array}{l}\text { (1) Collagen: twisted fibrils } \\
\text { with variable diameter, } \\
\text { bundles of variable size; } \\
\text { (2) fibroblasts: dilated } \\
\text { ER filled with granular } \\
\text { material; (3) } \\
\text { interstitium: enlarged; } \\
\text { (4) elastic fibers: normal } \\
\text { structure, excessive } \\
\text { amount; (5) excessive } \\
\text { amorphous matrix. }\end{array}$ & $\begin{array}{l}\text { Possible } \\
\text { EDS IV. }\end{array}$ \\
\hline $2 / 44 / \mathrm{F}$ & $\begin{array}{l}\text { Bilateral ICA } \\
\text { forming pseudo } \\
\text { aneurysms and } \\
\text { stenosis left > } \\
\text { right; left ACA } \\
\text { stroke. }\end{array}$ & $\begin{array}{l}\text { No. Occurred } \\
\text { when doing } \\
\text { standard } \\
\text { dancing. } \\
\text { Migraine. }\end{array}$ & $\begin{array}{l}\text { Short-lasting } \\
\text { akinetic } \\
\text { mutism. }\end{array}$ & No. & $\begin{array}{l}\text { Disorganized collagen } \\
\text { bundles and elastic } \\
\text { fibers; rare } \\
\text { dendrocytes. }\end{array}$ & $\begin{array}{l}\text { (1) Collagen: fibrils of } \\
\text { variable diameter, } \\
\text { disorganized thin } \\
\text { bundles; (2) fibroblasts: } \\
\text { dilated ER filled with } \\
\text { granular material; (3) } \\
\text { excessive amorphous } \\
\text { matrix; (4) elastic fibers: } \\
\text { fragmented or "moth- } \\
\text { eaten." }\end{array}$ & EDS. \\
\hline $3 / 29 / \mathrm{M}$ & $\begin{array}{l}\text { Left VA, small } \\
\text { stroke of the } \\
\text { left } \\
\text { dorsolateral } \\
\text { medulla } \\
\text { oblongata. }\end{array}$ & $\begin{array}{l}\text { No. Overhead } \\
\text { work the week } \\
\text { before. }\end{array}$ & $\begin{array}{l}\text { Wallenberg } \\
\text { syndrome. }\end{array}$ & No. & Normal. & $\begin{array}{l}\text { (1) Collagen: small } \\
\text { bundles, irregular } \\
\text { interfibrillar spaces, } \\
\text { small diameter fibrils; } \\
\text { (2) excessive amorphous } \\
\text { matrix; (3) elastic fibers: } \\
\text { focal fragmentation. }\end{array}$ & $\begin{array}{l}\text { Possible } \\
\text { EDS IV. }\end{array}$ \\
\hline $4 / 34 / \mathrm{M}$ & $\begin{array}{l}\text { Left ICA. } \\
\text { Superficial left } \\
\text { MCA stroke. }\end{array}$ & No. & $\begin{array}{l}\text { Global aphasia, } \\
\text { ideomotor } \\
\text { apraxia. }\end{array}$ & $\begin{array}{l}\text { Hypermobile } \\
\text { joints and } \\
\text { skin, } \\
\text { molluscoids. }\end{array}$ & $\begin{array}{l}\text { Disorganized collagen } \\
\text { bundles and elastic } \\
\text { fibers. Rare } \\
\text { dendrocytes. }\end{array}$ & $\begin{array}{l}\text { (1) Collagen: bundles of } \\
\text { variable sizes, small } \\
\text { diameter fibrils, } \\
\text { disorganized bundles; (2) } \\
\text { fibroblasts; dilated ER } \\
\text { filled with granular } \\
\text { material; (3) excessive } \\
\text { diffuse matrix with } \\
\text { granular deposits; (4) } \\
\text { elastic fibers: normal. }\end{array}$ & EDS. \\
\hline $5 / 34 / \mathrm{F}$ & $\begin{array}{l}\text { ICA bilateral } \\
\text { with left } \\
\text { stenosis, } \\
\text { parietal left } \\
\text { MCA stroke. }\end{array}$ & $\begin{array}{l}\text { No. Occurred } \\
\text { during supper. } \\
\text { Left-sided facial } \\
\text { pain and } \\
\text { malaise the } \\
\text { weeks before. }\end{array}$ & $\begin{array}{l}\text { Fluent mixed } \\
\text { aphasia when } \\
\text { challenged } \\
\text { (orthostatically, } \\
\text { stress). }\end{array}$ & No. & Normal. & Normal. & Normal. \\
\hline $6 / 45 / \mathrm{F}$ & $\begin{array}{l}\text { Left ICA. No } \\
\text { stenosis, no } \\
\text { stroke. }\end{array}$ & $\begin{array}{l}\text { Chiropraxia } 3 \\
\text { weeks before. } \\
\text { Migraine. }\end{array}$ & $\begin{array}{l}\text { Local pain, } \\
\text { ipsilateral } \\
\text { Horner } \\
\text { syndrome. }\end{array}$ & No. & $\begin{array}{l}\text { Disorganized collagen } \\
\text { and elastic fibers; } \\
\text { normal looking } \\
\text { dendrocytes. }\end{array}$ & $\begin{array}{l}\text { (1) Collagen: bundles of } \\
\text { variable sizes, twisted } \\
\text { fibrils, irregular } \\
\text { interfibrillar spaces; (2) } \\
\text { fibroblasts: dilated ER; } \\
\text { (3) elastic fibers: normal. }\end{array}$ & EDS. \\
\hline $7 / 48 / \mathrm{M}$ & $\begin{array}{l}\text { Left ICA, } \\
\text { subtotal MCA- } \\
\text { and AChA- } \\
\text { stroke. }\end{array}$ & No. & $\begin{array}{l}\text { Global aphasia, } \\
\text { apraxia, left } \\
\text { sensorimotor } \\
\text { hemiplegia. }\end{array}$ & No. & $\begin{array}{l}\text { Clumps of elastic } \\
\text { fibers with uneven } \\
\text { sizes. }\end{array}$ & Normal. & Elastopathy. \\
\hline
\end{tabular}

CTD = connective tissue disorder; ICA = internal carotid artery; MCA = middle cerebral artery; ER = endoplasmic reticulum; EDS = Ehlers-Danlos syndrome; ACA = anterior cerebral artery; AChA = anterior choroidal artery; VA = vertebral artery.

SCAD. EDS encompasses a heterogeneous group of CTDs chiefly characterized by various combinations of cutaneous hyperextensibility and fragility, joint laxity, vascular and visceral ruptures, and skeletal deformities. Obviously, the Villefranche classification does not yet recognize EDS variants with other manifestations that can be identified by objective morphologic, functional, and instrumental quantifications. ${ }^{6-8}$ Crosssectional studies of full-blown EDS type IV indicate a SCAD risk for $\sim 2 \%$ of the patients, which seems low for EDS IV but elevated regarding SCAD. ${ }^{3}$ These EDS-like changes indicate a fragile collagen. Although the prevalence of these dermal changes in the general population is unknown, a pure coincidence is merely probable. It remains open whether we are dealing with a variant of EDS IV or a new variant of CTD. We did not attempt genetic analysis because the results in several studies investigating genes causing CTD were negative in patients with SCAD. ${ }^{2,9}$ The data on EDS IV suggest that despite following an autosomal-dominant trait, phenotype and age of presentation can vary considerably. ${ }^{3}$ New mutations may occur in up to $50 \%$. These data need to be validated by a study that blinds the pathologist to the clinical presentation and includes genetic analysis. 


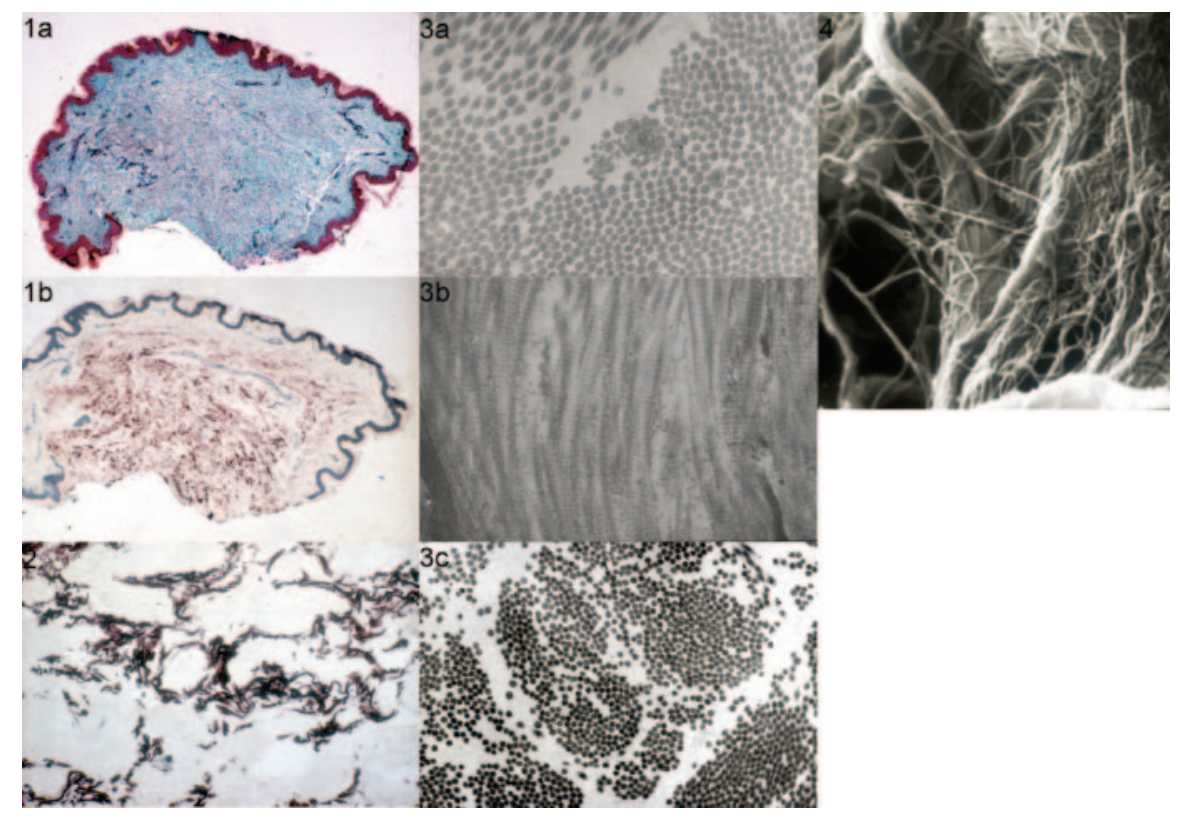

Figure. (1) Typical retraction in the deep layers of a skin biopsy in EhlersDanlos syndrome: (a) Masson trichrome coloration disclosing irregular collagen; and (b) orcein coloration showing irregular and dense net of elastic fibers. (2) Abnormal elastic fibers. (3) Electron microscopy: (a) with an abnormal collagen fibril ("cauliflowerlike"); (b) twisted collagen fibrils with granulofilamentous deposits; and (c) small collagen bundles with irregular interfibrillar spaces. (4) Scanning electron microscopy: loose-packed arrangement of the collagen fibrils.

\section{References}

Ehlers-Danlos syndromes: revised nosology, Villefranche 1997. Am J Hum Genet 1998;77:31-37.

1. Leys D, Bandu L, Hénon H, et al. Clinical outcome in 287 consecutive patients with stroke at the age of 15 to 45 . Neurology 2002;59:2633.

2. Brandt T, Grond-Ginsbach C. Spontaneous cervical artery dissection: from risk factors towards pathogenesis. Stroke 2002;33:657-658.

3. Pepin M, Schwarze U, Superti-Furga A, Byers PH. Clinical and genetical features of Ehlers-Danlos syndrome type IV, the vascular type. N Engl J Med 2000;342:673-680.

4. Brandt T, Orberk E, Weber R, et al. Pathogenesis of cervical artery dissections. Neurology 2001;57:24-30.

5. Beighton P, De Paepe A, Steinmann B, Tsipouras P, Wenstrup RJ.

6. Piérard GE, Piérard-Franchimont C, Lapière CM. Histopathological aid at the diagnosis of Ehlers-Danlos syndrome, gravis and mitis types. Int $J$ Dermatol 1983;22:300-304.

7. Henry F, Goffin V, Piérard-Franchimont C, Piérard GE. Mechanical properties of skin in Ehlers-Danlos syndrome, type I, II and III. Pediatr Dermatol 1996;13:464-467.

8. Hermanns-Lê T, Piérard GE. Factor XIIIa-positive dendrocyte rarefaction in Ehlers-Danlos syndrome classic type. Am J Dermatopathol 2001; $23: 427-430$

9. von Pein F, Välkkilä M, Schwarz R, et al. Analysis of the COL3A1 gene in patients with spontaneous cervical artery dissections. J Neurol 2002; 249:862-866. 


\section{Cervical artery dissection: An atypical presentation with Ehlers-Danlos-like collagen pathology?}

D. Ulbricht, N. J. Diederich, T. Hermanns-Lê, R. J. Metz, F. Macian and G. E. Piérard Neurology 2004;63;1708-1710

\section{This information is current as of March 3, 2009}

\section{Updated Information \\ \& Services}

Subspecialty Collections

Permissions \& Licensing

Reprints including high-resolution figures, can be found at: http://www.neurology.org/cgi/content/full/63/9/1708

This article, along with others on similar topics, appears in the following collection(s):

All Cerebrovascular disease/Stroke

http://www.neurology.org/cgi/collection/all_cerebrovascular_disea se_stroke Carotid artery dissection

http://www.neurology.org/cgi/collection/carotid_artery_dissection

Information about reproducing this article in parts (figures, tables) or in its entirety can be found online at:

http://www.neurology.org/misc/Permissions.shtml

Information about ordering reprints can be found online: http://www.neurology.org/misc/reprints.shtml 